\title{
The Use of Electrochemical Voltammetric Techniques and High-Pressure Liquid Chromatography to Evaluate Conjugation Efficiency of Multiple Sclerosis Peptide-Carrier Conjugates
}

\author{
Efstathios Deskoulidis ${ }^{1}\left(\mathbb{D}\right.$, Sousana Petrouli ${ }^{1}$, Vasso Apostolopoulos ${ }^{2}{ }^{\circledR}$, John Matsoukas ${ }^{2,3,4, *}$ \\ and Emmanuel Topoglidis $1, *$ (D) \\ 1 Materials Science Department, University of Patras, 26504 Patras, Greece; stathis.deskou@gmail.com (E.D.); \\ sousanapetr@gmail.com (S.P.) \\ 2 Institute for Health and Sport, Victoria University, Melbourne, VIC 3030, Australia; \\ vasso.apostolopoulos@mail.com \\ 3 Newdrug, Patras Science Park, 26500 Patras, Greece \\ 4 Department of Physiology and Pharmacology, Cumming School of Medicine, University of Calgary, Alberta, \\ AB T2N 4N1, Canada \\ * Correspondence: imats1953@gmail.com (J.M.); etop@upatras.gr (E.T.)
}

Received: 30 June 2020; Accepted: 17 August 2020; Published: 21 August 2020

check for updates

\begin{abstract}
Recent studies have shown the ability of electrochemical methods to sense and determine, even at very low concentrations, the presence and quantity of molecules or analytes including pharmaceutical samples. Furthermore, analytical methods, such as high-pressure liquid chromatography (HPLC), can also detect the presence and quantity of peptides at very low concentrations, in a simple, fast, and efficient way, which allows the monitoring of conjugation reactions and its completion. Graphite $/ \mathrm{SiO}_{2}$ film electrodes and HPLC methods were previously shown by our group to be efficient to detect drug molecules, such as losartan. We now use these methods to detect the conjugation efficiency of a peptide from the immunogenic region of myelin oligodendrocyte to a carrier, mannan. The HPLC method furthermore confirms the stability of the peptide with time in a simple one pot procedure. Our study provides a general method to monitor, sense and detect the presence of peptides by effectively confirming the conjugation efficiency. Such methods can be used when designing conjugates as potential immunotherapeutics in the treatment of diseases, including multiple sclerosis.
\end{abstract}

Keywords: mannan; peptide; conjugation; $\mathrm{MOG}_{35-55}$; Graphite/SiO 2 electrode; voltammetry; $\mathrm{HPLC}$; multiple sclerosis; immunotherapy; vaccine

\section{Introduction}

Voltammetric techniques, including differential pulse voltammetry (DPV) and cyclic voltammetry $(\mathrm{CV})$, as well as high-performance liquid chromatography (HPLC), were applied to identify and detect a peptide to its conjugated carrier. This study describes for the first time an alternative, fast, low cost and reliable method for the adequate and reliable determination of an active pharmaceutical ingredient (API) in the biocompatible matrix. The performance of the voltammetric techniques is strongly dependent on the performance of the working electrode used. Film electrodes, such as the graphite/ $\mathrm{SiO}_{2}$ used in this study, are being used in electrochemistry, as it has a number of advantages over the standard metallic and glass carbon electrodes. These include ease of manufacture requiring lower temperatures, low cost, the high surface area that could be rapidly renovated, simple handling, 
and their increased conductivity in a wide range of potentials. In addition, these techniques exhibit a wide range of anodic and cathodic peaks and great electrocatalytic activity and stability. All these features are crucial for the correct choice of a working electrode, especially when direct electrochemistry is conducted [1]. We recently demonstrated that these film electrodes modified or not, could be used for electrochemical drug sensing, for validation in food chemistry, and for the immobilization of heme proteins for studying protein/electrode interaction [2-4]. The electrochemical analytical methods were recently applied effectively in the detection of anti-hypertensive drug losartan [3] and have applied this method to detect peptides in peptide-carrier conjugates. The peptide used was the multiple sclerosis (MS) immunogenic peptide from myelin oligodendrocyte ( $\left.\mathrm{MOG}_{35-55}\right)$.

Numerous methods have been established for the analytical determination of drugs at low concentrations, using state of the art systems, such as HPLC, high-performance thin-layer chromatography and capillary electrophoresis/capillary electrochromatography [3]. Although these methods provide very accurate and reliable data, they are costly, time consuming, and involve the use of expensive equipment and consumables. In addition, sample pre-treatment is usually necessary. In this sense, electrochemical methods have emerged as low cost, reliable alternatives for the characterization of peptides and drugs. Different electrochemical techniques, involving voltammetry or potentiometry, have been implemented for drug analysis, as they offer ease of preparation and operation, high sensitivity, fast response time, high quantification and detection limits, reasonable selectivity, wide linear range, and are cost effective [3]. In this regard, we applied voltammetry techniques to monitor the conjugation of a peptide to its carrier, for the first time as a proof of concept study.

MS is regarded an autoimmune disease where immune cells (such as, Th1, Th17, macrophages, $\mathrm{B}$ cells) and their constituents (pro-inflammatory cytokines) are involved in the pathophysiology of the disease, with destruction of myelin sheath and loss of neurological function [5-10]. In an attempt to develop immunotherapeutics against MS using immunogenic/agonist peptides is to either alter the peptide to make it an antagonist [11-16], make it cyclic [17-19], or conjugate it to an appropriate carrier, which would deliver the peptide in such a manner to either induce tolerance, or alter the profile of $\mathrm{T}$ cells from pro-inflammatory (Th1) to anti-inflammatory (Th2) [13-15]. One approach which our team has developed, is to use mannan, a poly-mannose carrier conjugated to MS peptides [20-24]. This approach was developed over 25 years ago by the group of Apostolopoulos et al., to be effective in targeting peptides and proteins to dendritic cells in a number of different cancer vaccine models, some of which were translated to human clinical trials [25-32]. As such, mannan was used as a carrier and conjugated to immunodominant MS peptides including $\mathrm{MBP}_{83-99}, \mathrm{PLP}_{139-141}$, and $\mathrm{MOG}_{35-55}$ or their analogues, and were shown in animal models to tolerize T cells or switch Th1 cells to Th2 cells, depending on the peptide analogue used and showed stimulation of Th2 cells in peripheral blood mononuclear cells from patients with MS [17,21,33-35]. The conjugation of mannan, in its oxidized form (OM), to $\mathrm{MOG}_{35-55}$ peptide ( $\mathrm{MOG}_{35-55}$ was used as an example in this study) via a (Lys-Gly) $)_{5}$ linker $\left[(\mathrm{KG})_{5}\right]$ was used and evaluated $\left(\mathrm{OM}-(\mathrm{KG})_{5}-\mathrm{MOG}_{35-55}\right.$ conjugate) using voltammetric techniques [1-4,36-38]. The conjugation between $\mathrm{OM}$ and peptide $\left(\mathrm{MOG}_{35-55}\right)$ occurs via formation of Schiff bases between the free amines of the linker $(\mathrm{KG})_{5}$ and aldehydes of OM. The synthesis and efficacy of these conjugates have been described in numerous studies $[23,24,39,40]$. However, the extent of conjugation and the redox condition of the participating sugars, such as mannan, are most times assessed by high cost, complicated and lengthy analytical methods, such as capillary electrophoresis and polyacrylamide gel electrophoresis $[23,24,39,40]$.

Among the approaches used in recent years for the immunomodulation of MS, the conjugation of mannan with myelin peptides has shown much promise, including that of OM-(KG) $)_{5}-\mathrm{MOG}_{35-55}$, which induces tolerance in mice, providing a promising conjugate for further studies. The electrochemical and HPLC analysis for identification of peptides or their mutants in mannan based conjugates requires specialized techniques, which differ significantly from those methods used for small molecules. In this study, novel analytical methods were developed and applied, that clearly, 
sense, detect, and confirm the conjugation of $\mathrm{OM}_{\text {with }} \mathrm{MOG}_{35-55}$. Further, this study makes it possible to accurately evaluate the stability of the peptide component in the conjugate using HPLC [41,42].

\section{Materials and Methods}

\subsection{Materials}

Sodium metasilicate $\left(\mathrm{Na}_{2} \mathrm{SiO}_{3}\right)\left(\mathrm{SiO}_{2}, 50-53 \%\right), \mathrm{NaH}_{2} \mathrm{PO}_{4}$, mannan isolated from yeast cells (Saccharomyces cerevisiae), potassium ferricyanide, ferrocyanide, and potassium chloride were obtained from Sigma Aldrich Chemie GmbH (Taufkirchen, Germany). $\mathrm{MOG}_{35-55}$ and $\mathrm{MOG}_{37-55}$ peptides were supplied by NewDrug S.A., Patras Science Park, Greece and purchased from China peptides Inc. The peptide analogue (Lys-Gly) ${ }_{5}-\mathrm{MOG}_{35-55}$, referred as $(\mathrm{KG})_{5}-\mathrm{MOG}_{35-55}$, was synthesized using standard peptide chemistry techniques and previously published by our group. Briefly, Fmoc/tBu methodology was used which included 2-chlorotrityl chloride resin (CLTR-Cl) and Na-Fmoc (9-fluorenylmethyloxycarboxyl) side chain protected amino acids $[43,44]$. The purity of the peptides were shown to be $>97 \%$ by analytical HPLC. Graphite powder (synthetic, APS 7-11 $\mu \mathrm{m}, 99 \%$ ) was obtained from Alfa Aesar. Soda lime glass slides $(75 \mathrm{~mm} \times 25 \mathrm{~mm} \times 1.1 \mathrm{~mm}$ ), with $15 \mathrm{Ohm} / \mathrm{sqr}$ Indium Tin Oxide (ITO) coating were obtained from PsiOTec, UK. All chemicals were of analytical grade and used without the need for further purification. All solutions were prepared in deionized water with resistance $\mathrm{R}=18 \mathrm{M} \Omega \mathrm{cm}$.

\subsection{Graphite/SiO $\mathrm{S}_{2}$ Film Electrodes Preparation}

The graphite/ $\mathrm{SiO}_{2}$ film electrodes were prepared as described [2,3]. Briefly, silicate liquid polymer $\left(50 \% \mathrm{Na}_{2} \mathrm{SiO}_{3} ; \mathrm{pH} 12-13\right)$ was gently mixed with $20 \%$ graphite powder at $23{ }^{\circ} \mathrm{C}$, until the mixture became homogeneous and acquired a "sticky" texture. The mixture underwent ultrasonication for $2 \mathrm{~min}$ for the graphite powder to be fully soluble, and $100 \mu \mathrm{L}$ of the silicate/graphite suspension were applied on the surface of a conductive ITO glass slide using the "Doctor Blade" technique. Prior to the deposition of the silicate/graphite suspension, the ITO glass slides were cleaned in a detergent solution using an ultrasonic bath for $15 \mathrm{~min}$, and then rinsed with $18 \mathrm{M} \Omega$ distilled water and ethanol. Each glass slide was masked with 3M Magic Scotch tape (thickness $62.5 \mu \mathrm{m}$; type 810), in order to control the width and the thickness of the mixture spread area. For each graphite/ $\mathrm{SiO}_{2}$ film deposition, one layer of tape was used which provided a size $1 \times 1 \mathrm{~cm}^{2}$ and film thickness of $\sim 66 \mu \mathrm{m}$. The films were allowed to dry for $30 \mathrm{~min}$ in a class 4000 room, prior to placing them in a preheated oven $\left(330{ }^{\circ} \mathrm{C}\right)$ for $100 \mathrm{~min}$. If required, the liquid suspension could be stored in an insulated flask at $25{ }^{\circ} \mathrm{C}$ for later usage. The resulting ITO substrates with the deposited graphite/ $\mathrm{SiO}_{2}$ films were cut in $10 \mathrm{~mm} \times 25 \mathrm{~mm}$ pieces before use.

\subsection{Characterization of Graphite/SiO $\mathrm{S}_{2}$ Film Electrodes}

Field emission scanning electron microscopy (FE-SEM) using an FEI inspect microscope ( $25 \mathrm{kV})$ was used to determine morphology and thickness of the Graphite/ $\mathrm{SiO}_{2}$ film. The films were prepared by AU sputtering to increase the conductivity of the samples. Energy dispersive spectroscopy EDS was also used for the elemental analysis of the Graphite/ $\mathrm{SiO}_{2} / \mathrm{ITO}$ films.

\subsection{Preparation of $(K G)_{5}-M O G_{35-55}$ Peptide}

MOG $_{35-55}$ agonist peptide was synthesized in our labs, $>97 \%$ purity, with $(K G)_{5}$ extended at the $\mathrm{N}$-terminus of the peptide. Peptide was prepared using our methods, either by coupling, catalyzed by microwave radiation in a CEM Liberty microwave system or by using the conventional step by step procedure by solid phase peptide methods (as described in [45]). (KG) $-\mathrm{MOG}_{35-55}$ peptide was also purchased by China Peptides Inc. In house synthesized peptides and purchased peptides were confirmed by HPLC and Mass Spectroscopy for purity and identity. 


\subsection{Preparation of Oxidized Mannan}

Mannan (14 mg) was dissolved in $1 \mathrm{~mL}$ phosphate buffer (0.1 M sodium phosphate, $\mathrm{pH}$ 6.0), and was oxidized using $0.1 \mathrm{M}$ sodium periodate and incubated at $4{ }^{\circ} \mathrm{C}$ for $1 \mathrm{~h}$, after which $10 \mu \mathrm{L}$ ethanediol was added for $30 \mathrm{~min}$ at $4{ }^{\circ} \mathrm{C}$. Oxidized mannan (OM) was passed through a PD-10 column (Sigma Aldrich Chemie) pre-equilibrated in sodium bicarbonate buffer (sodium carbonate: Sodium bicarbonate, $\mathrm{pH}$ 9.0). Two $\mathrm{ml}$ of $\mathrm{OM}$ fraction $(7 \mathrm{mg} / \mathrm{mL})$ was collected and kept in the dark.

\subsection{Conjugation of Oxidized Mannan to Peptide}

To the OM fraction ( $2 \mathrm{~mL} ; 7 \mathrm{mg} / \mathrm{mL}$, sodium bicarbonate $\mathrm{pH} 9.0$ buffer), $1 \mathrm{mg}$ of (KG) $)_{5}-\mathrm{MOG}_{35-55}$ peptide was added and allowed to react overnight in the dark at $23^{\circ} \mathrm{C}$. A list of peptides and conjugates are summarized in Table 1.

Table 1. Peptides and conjugates used in this study.

\begin{tabular}{cr}
\hline \multicolumn{1}{c}{ Acronym } & \multicolumn{1}{c}{ Specification } \\
\hline $\mathrm{MOG}_{35-55}$ & Myelin oligodendrocyte glycoprotein immunogenic epitope, region 35-55 \\
\hline $\mathrm{MOG}_{37-55}$ & Myelin oligodendrocyte glycoprotein immunogenic epitope, region 37-55 \\
\hline$(\mathrm{KG})_{5}-\mathrm{MOG}_{35-55}$ & Peptide analogue $\mathrm{MOG}_{35-55}$ with $(\mathrm{KG})_{5}$ at the N-terminus \\
\hline $\mathrm{OM}-(\mathrm{KG})_{5}-\mathrm{MOG}_{35-55}$ & Oxidized mannan conjugated to $(\mathrm{KG})_{5}-\mathrm{MOG}_{35-55}$ \\
\hline $\mathrm{KG}$, lysine glycine; $\mathrm{MOG}$, myelin oligodendrocyte glycoprotein; OM, oxidized mannan.
\end{tabular}

\subsection{Monitoring of Conjugation by HPLC}

We used a Waters 2695 HPLC (Alliance) system with a photodiode array detector equipped with a Lichrosorb RP-18 reversed phase analytical column (C18 $35 \mu \mathrm{m}, 4.6 \times 50 \mathrm{~mm}$ PIN 186003034). Analysis was achieved with stepped linear gradient of solvent $\mathrm{A}\left(0.08 \%\right.$ TFA in $\left.\mathrm{H}_{2} \mathrm{O}\right)$ and in solvent $\mathrm{B}(0.08 \%$ TFA in $100 \%$ acetonitrile) for $30 \mathrm{~min}$ with a flow rate $3 \mathrm{~mL} / \mathrm{min}$. The conjugation of OM with $(\mathrm{KG})_{5}-\mathrm{MOG}_{35-55}$ peptide was evaluated by HPLC. The (KG) $)_{5}-\mathrm{MOG}_{35-55}$ HPLC peak disappeared within six hours indicating completion of conjugation to $\mathrm{OM}$.

\subsection{Electrochemical/Electrocatalytic Measurements}

Electrochemical measurements were conducted using an Autolab PGStat-101 potentiostat (Metrohm, Utrecht, The Netherlands). The electrochemical cell comprised of a $10 \mathrm{~mL}$, three-electrode stirring glass cell with a Teflon cap, a platinum mesh flag as the counter electrode, a $\mathrm{Ag} / \mathrm{AgCl} / \mathrm{KCl}$ sat reference electrode and a Graphite/ $\mathrm{SiO}_{2}$ film on ITO conducting glass as the working electrode. The electrolyte contained a solution of $\mathrm{NaH}_{2} \mathrm{PO}_{4}(10 \mathrm{mM}$; $\mathrm{pH} 7.0)$, which was deoxygenated with argon prior to any measurements and an argon atmosphere was kept throughout the measurements. The DPV measurements took place in a potential range between -1 to $+0.05 \mathrm{~V}$. The optimized parameters of DPV correspond to a step potential at $5 \mathrm{mV}$, amplitude of $50 \mathrm{mV}$, modulation time of $25 \mathrm{~ms}$ with scan rate $100 \mathrm{mV} \mathrm{s}^{-1}$ and a frequency of $50 \mathrm{~Hz}$. All potentials are reported against $\mathrm{Ag} / \mathrm{AgCl}$ and all experiments were carried out at $23^{\circ} \mathrm{C}$.

\section{Results and Discussion}

\subsection{FE-SEM Characterization}

The general thickness and surface morphology of the graphite/ $\mathrm{SiO}_{2}$ films were demonstrated by FE-SEM. The top-view of the FE-SEM image (Figure 1a) shows that the surface of the graphite/ $/ \mathrm{SiO}_{2}$ film is rough and non-uniform with many wrinkles. It exhibits increased porosity and a high effective surface area. Figure $1 \mathrm{~b}$ presents the cross section of a graphite $/ \mathrm{SiO}_{2}$ film electrode, with an estimated film thickness of $\sim 65 \mu \mathrm{m}$ as set by the adhesive tape used; the $\mathrm{EDS}$ for a graphite/ $/ \mathrm{SiO}_{2}$ film carried out during 
the FE-SEM analysis is shown in the Supplementary Materials (SM, Figure S1). The characteristic peaks of $\mathrm{Na}, \mathrm{O}$, and $\mathrm{Si}$, due to the use of silicate glue $\left(\mathrm{Na}_{2} \mathrm{SiO}_{3}\right)$, are presented in high intensity, thus, the peak of $C$ is presented in lower intensity. Hence, the results validate the reduced concentration of carbon in the mixture used for the fabrication of the graphite/ $\mathrm{SiO}_{2}$ films.

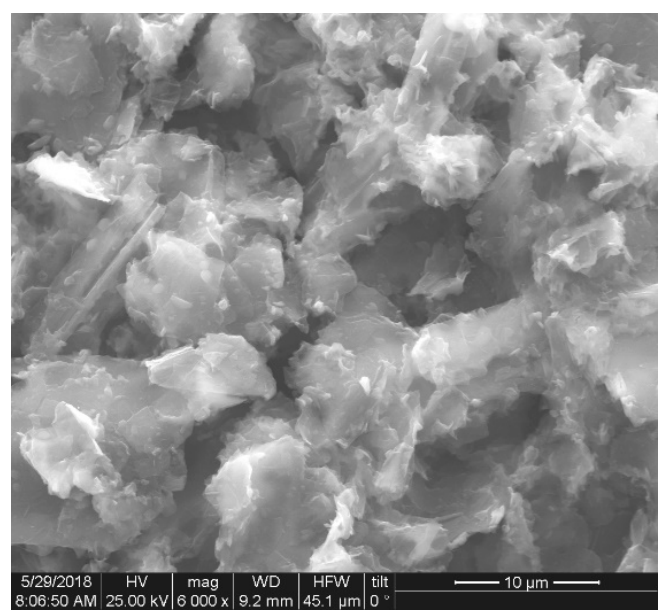

(a)

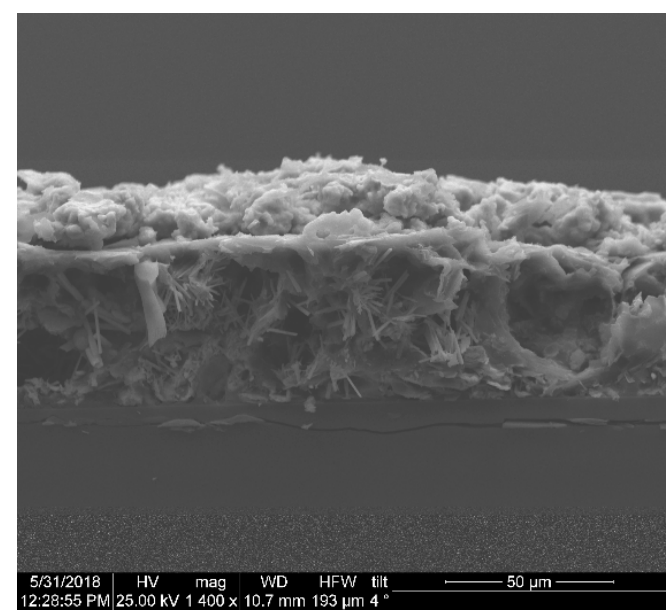

(b)

Figure 1. SEM images of the graphite/ $\mathrm{SiO}_{2}$ working electrode from (a) top view and (b) a cross section.

\subsection{UV Characterazation of $(K G)_{5}-M_{35-55}$ Peptide with Increasing Amounts of $O M$}

It is known that most peptides exhibit strong absorbance at around $280 \mathrm{~nm}$, due to aromatic amino acids (tyrosine and tryptophan) or disulfide bonds in the peptide sequences [46,47]. Figure 2 shows the UV-vis spectra of $(\mathrm{KG})_{5}-\mathrm{MOG}_{35-55}$ with increasing amounts of $\mathrm{OM}$. The increase of absorbance at $280 \mathrm{~nm}$ confirms the conjugation of $\mathrm{MOG}_{35-55}$ peptide to OM. The intensity of the absorption peak at 280 increases until all of the free peptide in solution is conjugated to the OM. It should be noted that the conjugate of $(\mathrm{KG})_{5}-\mathrm{MOG}_{35-55}$ with $\mathrm{OM}$ took place in solution and not on the surface of the graphite/ $\mathrm{SiO}_{2}$ film electrode as due to its non-transparency it is impossible to monitor the conjugation process on its surface. All the UV-visible absorption spectra of the peptide was recorded using a Shimadzu UV-1800 spectrophotometer.

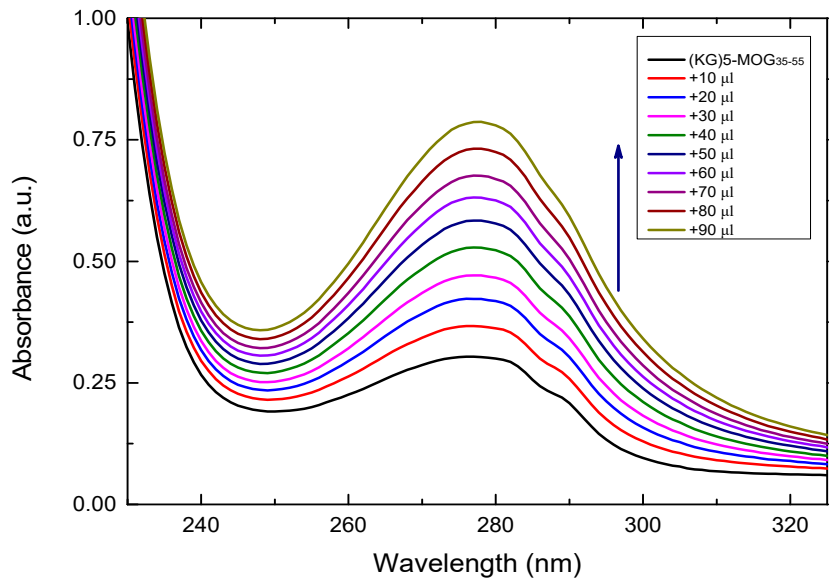

Figure 2. UV-Vis spectral changes of $(\mathrm{KG})_{5}-\mathrm{MOG}_{35-55}$ in solution with increasing amounts of OM $(10-90 \mu \mathrm{L})$. 


\subsection{Electrochemical Analysis Showing Conjugation of (KG) $)_{5}-M O G_{35-55}$ to $O M$}

Electrochemical characteristics of the graphite $/ \mathrm{SiO}_{2}$ film electrode were investigated by $\mathrm{CV}$. Figure 3a shows the electrochemical behavior of a bare graphite $/ \mathrm{SiO}_{2}$ film electrode in a solution of 0.1 $\mathrm{M} \mathrm{KCl}$ and $5 \mathrm{mM}$ of $\left[\mathrm{Fe}(\mathrm{CN})_{6}\right]^{3-/ 4-}$ through $\mathrm{CV}$ in the potential range of +1 to $-1 \mathrm{~V}$ at different scan rates. Figure $3 \mathrm{~b}$ shows the currents (anodic and cathodic) from the plots of I vs. square root of scan rate $\left(v^{1 / 2}\right)$. Straight lines form for both the anodic and cathodic currents, confirming that a diffusional process has occurred in the reaction of ferrocyanide/ferricyanide. In addition, these results confirm that fast electron transfer occurs on the Graphite/ $\mathrm{SiO}_{2}$ film electrode due to its increased conductivity and surface area. In order to calculate the electroactive surface area of the film electrode, the Randles-Sevcik equation was used [36]:

$$
i_{p}=\left(2.69 \times 10^{5}\right) \times A \times D^{1 / 2} \times n^{3 / 2} \times C \times v^{1 / 2}
$$

where $i_{p}$ corresponds to the maximum current (in Amperes), $n$ is the number of electrons transferred $(n=1), D$ is the diffusion coefficient $\left(\mathrm{cm}^{2} \mathrm{~s}^{-1}\right)$ of $\left[\mathrm{Fe}(\mathrm{CN})_{6}\right]^{3-/ 4-}$ solution $\left(7.6 \times 10^{-6} \mathrm{~cm}^{2} \mathrm{~s}^{-1}\right)$ [37], $A$ is the electrode area $\left(\mathrm{cm}^{2}\right), C$ is the concentration $\left(\right.$ molcm $\left.{ }^{-3}\right)$ and $v$ is the scan rate $\left(\mathrm{mV} \mathrm{s}^{-1}\right)$ and thus the electroactive surface area of the graphite $/ \mathrm{SiO}_{2}$ was estimated to be $0.0039 \mathrm{~cm}^{2}$.

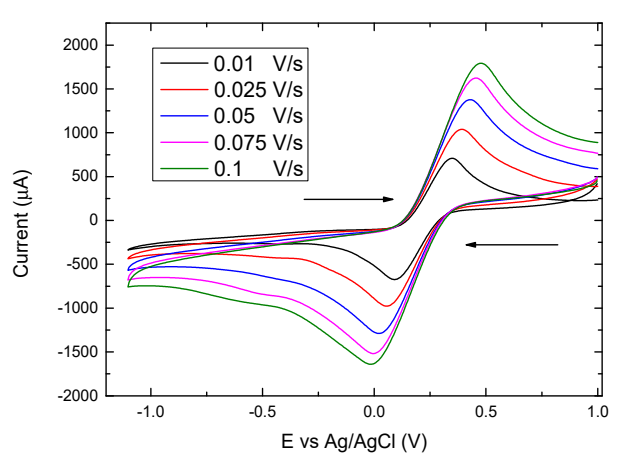

(a)

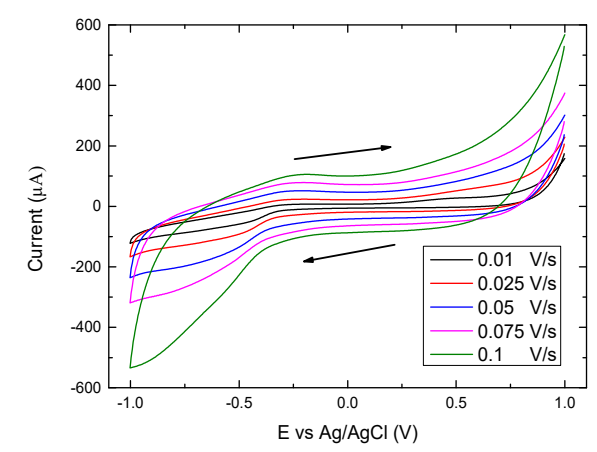

(c)

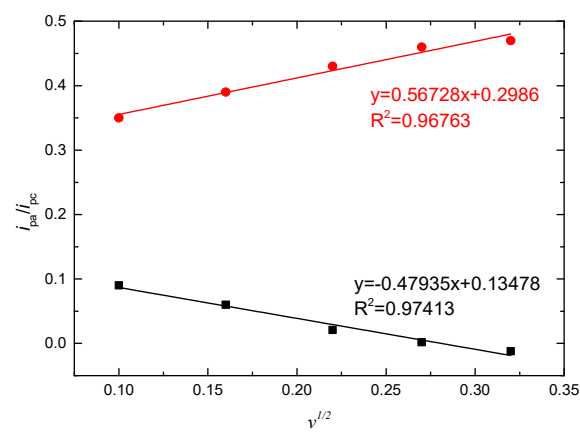

(b)

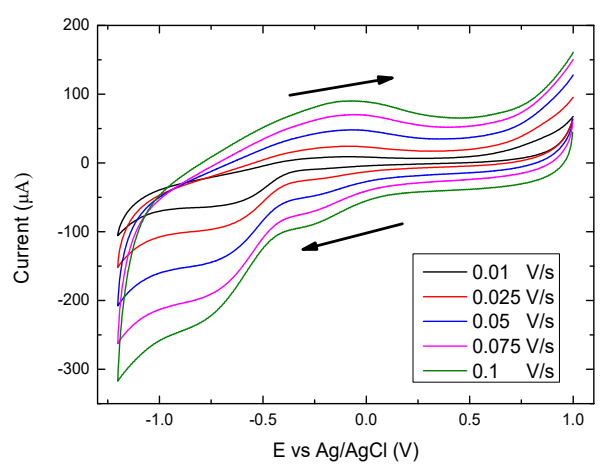

(d)

Figure 3. Cyclic voltammograms (CVs) of (a) a bare graphite $/ \mathrm{SiO}_{2}$ film electrode in $0.1 \mathrm{M} \mathrm{KCl}$ solution containing $5 \mathrm{mM}$ of $[\mathrm{Fe}(\mathrm{CN}) 6]^{3-/ 4-}$ at different scan rates. (b) Plot of anodic and cathodic peak current (Ipa/Ipc) vs. square root of scan rate $\left(v^{1 / 2}\right)$. (c) A bare graphite/SiO $\mathrm{S}_{2}$ film electrode in $10 \mathrm{mM} \mathrm{NaH} \mathrm{PO}_{4}$, $\mathrm{pH} 7.0$ at different scan rates and (d) the OM-(KG) $)_{5}-\mathrm{MOG}_{35-55}$ conjugate on graphite/ $\mathrm{SiO}_{2}$ in $10 \mathrm{mM}$ $\mathrm{NaH}_{2} \mathrm{PO}_{4}, \mathrm{pH} 7.0$ at different scan rates under an Argon atmosphere. 
The electrochemical behavior of the graphite/ $\mathrm{SiO}_{2}$ film electrode was then investigated in the presence and absence of the MS myelin epitope peptide vaccine (OM-(KG)5-MOG $35-55$ ). Figure $3 \mathrm{c}$ shows the effect of scan rate of a bare graphite/ $\mathrm{SiO}_{2}$ electrode, before the detection of the OM-(KG)5-MOG $35-55$, at a scan rate range of 0.01 to $0.1 \mathrm{~V} \mathrm{~s}^{-1}$. All electrochemical experiments were performed in a peptide free, anaerobic $10 \mathrm{mM} \mathrm{NaH}_{2} \mathrm{PO}_{4}\left(\mathrm{pH}\right.$ 7.0). The bare graphite/ $\mathrm{SiO}_{2}$ film electrode shows the characteristic charging/de-charging currents, and no cathodic or anodic peaks are observed even at the slowest scan rate $\left(0.01 \mathrm{~V} \mathrm{~s}^{-1}\right)$. One of the advantages of using graphite paste electrodes is the increased conductivity, which allows a broader study of redox reactions occurring at very high or low biases (ranging from +1 $\mathrm{V}$ to $-1 \mathrm{~V})$. Further, the slower scan rate applied, the smaller the resulting current is obtained. Figure $3 b$, on the other hand, showing the CVs of OM- $(\mathrm{KG})_{5}-\mathrm{MOG}_{35-55}$ on the graphite/ $\mathrm{SiO}_{2}$ film electrode, exhibits not only the characteristic charging/discharging currents assigned to electron injection into sub-band gap/conduction band states of the graphite/ $\mathrm{SiO}_{2}$ electrode, but also two reduction peaks around $-0.22 \mathrm{~V}$ and $-0.67 \mathrm{~V}$ and a broad re-oxidation peak at $-0.1 \mathrm{~V}$.

The redox peak currents were shown to be proportional to the scan rate, characteristic of quasi-reversible behavior. The rate of reaction between the graphite/ $\mathrm{SiO}_{2}$ electrode and the conjugate, $\mathrm{OM}-(\mathrm{KG})_{5}-\mathrm{MOG}_{35-55}$ was not fast enough to maintain equal concentrations of oxidized and reduced species at the surface of the electrode. In addition, the CV responses were shown to be stable, with the waveforms being unperturbed after being scanned several times, whilst no other consumption of the complex occurred nor other undesirable reactions in the phosphate buffer took place.

In Figure $3 \mathrm{~d}$, the two cathodic peaks at $-0.27 \mathrm{~V}$ and $-0.7 \mathrm{~V}$ and the wide anodic peak approximately at $-0.1 \mathrm{~V}$ observed are due to the presence of the OM-(KG) $)_{5}-\mathrm{MOG}_{35-55}$. The two cathodic peaks correspond to the linker molecule $(\mathrm{KG})_{5}$ used to conjugate the $\mathrm{MOG}_{35-55}$ peptide to $\mathrm{OM}$, that contains 5 lysines and 5 glycines to its structure. Thus, the cathodic peaks attributed to the presence of lysines. On the other hand, the wide oxidation peak occurred probably due to superfluity of the free $(\mathrm{KG})_{5}-\mathrm{MOG}_{35-55}$ peptide that was not able to conjugate to OM and created the final complex of the $\mathrm{OM}-(\mathrm{KG})_{5}-\mathrm{MOG}_{35-55}$ conjugate.

The CVs of the constituents of the OM-(KG) $-\mathrm{MOG}_{35-55}$ conjugate are shown in Figure 4. According to Figure $4 \mathrm{a}$, as mentioned earlier, the bare graphite $/ \mathrm{SiO}_{2}$ film electrode exhibited no reduction or oxidation peaks which is consistent with the currents being limited by the graphite conductivity at the voltage biases reported herein. On the other hand, the $\mathrm{CV}$ of the film electrode in the presence of mannan in $0.1 \mathrm{M}$ buffer exhibited an oxidation peak at approximately $0.5 \mathrm{~V}$, and the $\mathrm{CV}$ of the film electrode in the presence of $0.002 \mathrm{mg} / \mathrm{mL} \mathrm{OM}$ displayed a slight cathodic peak at $-0.56 \mathrm{~V}$ and the characteristic anodic peak at $-0.1 \mathrm{~V}$. At the same time, the electrochemical behavior of peptides $\mathrm{MOG}_{35-55}$ and $\mathrm{MOG}_{37-55}$ were examined. The main difference between these two peptides is that the $\mathrm{MOG}_{35-55}$ peptide contained and additional linker with 5 lysines $(\mathrm{KG})_{5}$, whilst the $\mathrm{MOG}_{37-55}$ peptide included a linker, which only contained 1 lysine. This was confirmed in Figure $4 \mathrm{~b}$, which displays the $\mathrm{CVs}$ of the Graphite/ $\mathrm{SiO}_{2}$ film electrode in the presence of each peptide. The two cathodic and anodic peaks observed are due to the presence of the lysine residues, however, the CV scan of the $\mathrm{MOG}_{35-55}$ peptide exhibits a higher current and a wider electrochemical window compared to the CV scan of $\mathrm{MOG}_{37-55}$ peptide, as the latter contained only 1 lysine residue.

DPV is a more sensitive approach compared to CV and hence, has been extensively used as a more sensitive method for the detection of molecules in low concentration [38]. In Figure 5, the DPVs are recorded for the bare film electrode, as well as for each part that constitutes the final structure of $\mathrm{OM}-(\mathrm{KG})_{5}-\mathrm{MOG}_{35-55}$ conjugate on the Graphite/ $\mathrm{SiO}_{2}$ working electrode. As can be seen in Figure $5 \mathrm{a}$, the bare graphite/ $\mathrm{SiO}_{2}$ is free of any redox peaks. However, in Figure $5 b$, there are two peaks which correspond to $(\mathrm{KG})_{5}-\mathrm{MOG}_{35-55}$ peptide, approximately at $-0.65 \mathrm{~V}$ and $-0.27 \mathrm{~V}$, respectively. Figure $5 \mathrm{c}$ shows the DPV of mannan (in $0.1 \mathrm{M}$ phosphate buffer) on the surface of the film electrode, displaying a clear sharper peak at around $-0.26 \mathrm{~V}$. The last step in order to evaluate the conjugation of peptide $(\mathrm{KG})_{5}-\mathrm{MOG}_{35-55}$ with OM via DPV measurements is depicted in Figure $5 \mathrm{~d}$ with a clear and distinct peak at $-0.28 \mathrm{~V}$ and a shoulder peak at $-0.62 \mathrm{~V}$, which are actually due to the presence of $\mathrm{OM}-(\mathrm{KG})_{5}-\mathrm{MOG}_{35-55}$ 
on the graphite $/ \mathrm{SiO}_{2}$ film electrode (after the addition of $0.002 \mathrm{mg} / \mathrm{mL}$ of OM). This is a proof of concept study, and we intend to further study the quantification of this and other conjugates, focusing on the limit od detection (LOD) of these conjugates using voltammetric techniques.

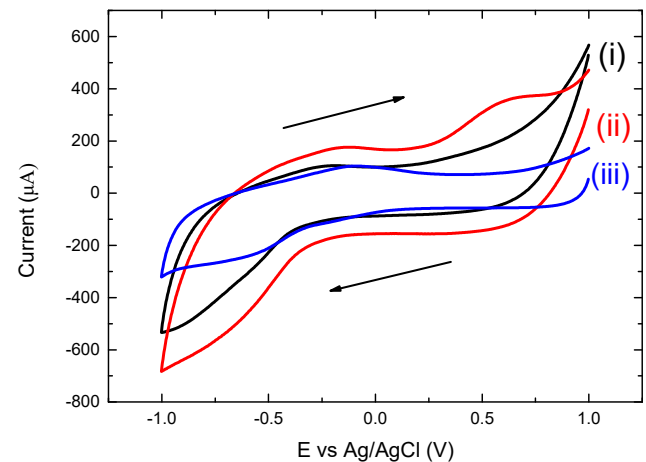

(a)

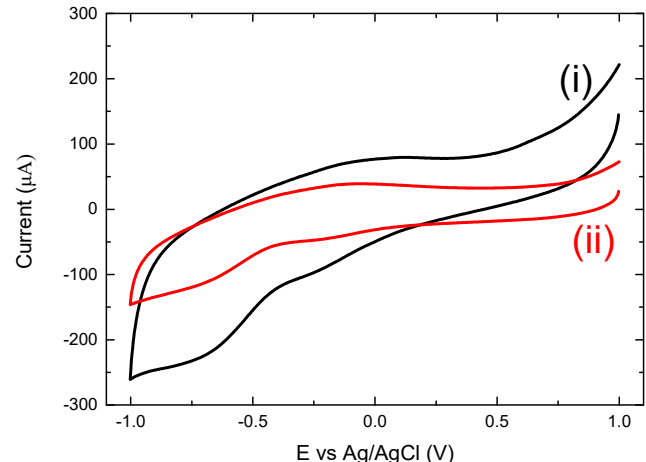

(b)

Figure 4. (a) CV scans at a scan rate of $0.1 \mathrm{Vs}^{-1}$ of (i) a bare graphite/ $\mathrm{SiO}_{2}$ film electrode, (ii) mannan and (iii) $\mathrm{OM}-(\mathrm{KG})_{5}-\mathrm{MOG}_{35-55}$ conjugate. (b) Depicts the comparison between the $\mathrm{CV}^{\prime} \mathrm{s}$ of (i) $\mathrm{MOG}_{35-55}$ and (ii) $\mathrm{MOG}_{37-55}$, both on graphite/ $\mathrm{SiO}_{2}$ in $10 \mathrm{mM} \mathrm{NaH}_{2} \mathrm{PO} 4, \mathrm{pH} 7.0$ at scan rate of $0.075 \mathrm{Vs}^{-1}$.

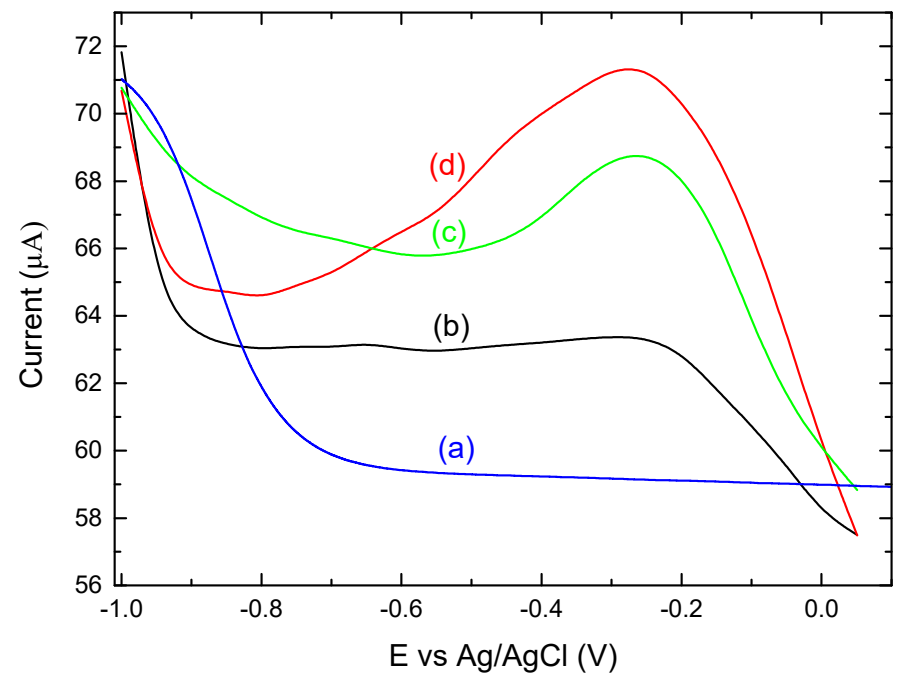

Figure 5. Differential pulse voltammetry (DPVs) comparison of (a) a bare graphite/ $\mathrm{SiO}_{2}$ film electrode, (b) $(\mathrm{KG})_{5}-\mathrm{MOG}_{35-55}$, (c) mannan, and (d) $\mathrm{OM}-(\mathrm{KG})_{5}-\mathrm{MOG}_{35-55}$ conjugate on graphite $/ \mathrm{SiO}_{2}$ electrode in $10 \mathrm{mM} \mathrm{NaH}_{2} \mathrm{PO}_{4}, \mathrm{pH}$ 7.0.

\subsection{Complete Conjugation between (KG) $)_{5}-M_{35-55}$ Peptide to OM is Monitored by HPLC}

Contrarily to the conjugation of $\mathrm{MOG}_{35-55}$ peptide with mannan, which did not occur, the reaction of $(\mathrm{KG})_{5}-\mathrm{MOG}_{35-55}$ with mannan (oxidized or not) resulted in gradual conjugation of (KG) $)_{5}-\mathrm{MOG}_{35-55}$ peptide within $6 \mathrm{~h}$ depicted in the gradual loss of the HPLC peak during this period (Figure 6). The amino groups of lysine residues within $(\mathrm{KG})_{5}$ forms a Schiff base reaction with the aldehyde groups of OM (resulting after the oxidation of mannan). The (KG) $)_{5}-\mathrm{MOG}_{35-55}$ peptide peak at 9.62 gradually disappears within this period, showing complete conjugation of $(\mathrm{KG})_{5}-\mathrm{MOG}_{35-55}$ peptide to OM. Figure $6 \mathrm{~b}$ shows the completion of conjugation within six hours. 

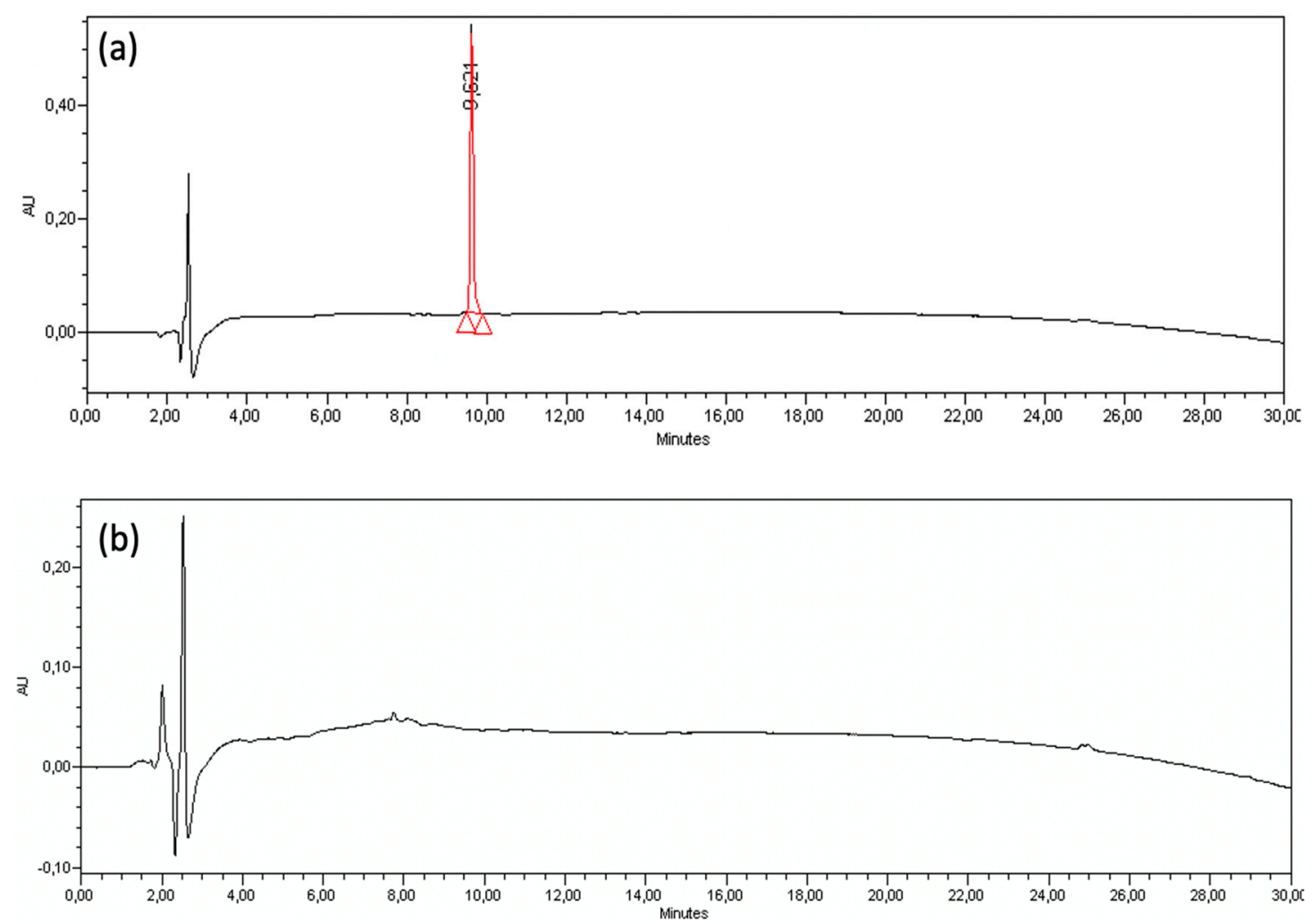

Figure 6. (a) High-performance liquid chromatography (HPLC) analysis of (KG) $)_{5}-\mathrm{MOG}_{35-55}-214 \mathrm{~nm}$ at the beginning of the conjugation reaction and (b) HPLC analysis of OM-(KG) $-\mathrm{MOG}_{35-55}$ solution after $6 \mathrm{~h}$.

\subsection{The Importance of the Linker $(K G)_{5}$ for Conjugation of Peptides to OM}

The conjugation of $\mathrm{MOG}_{35-55}$ peptide to $\mathrm{OM}$ was achieved through $(\mathrm{KG})_{5}$ linker, as previously described [23]. As demonstrated, this approach provides simple and efficient conjugation by the Schiff base reaction, where aldehyde groups of $\mathrm{OM}$ reacts with the amino groups of the lysine side chains of the $(\mathrm{KG})_{5}-\mathrm{MOG}_{35-55}$, peptide. In previous similar studies using the linker $\mathrm{KG}$ of varying lengths, $(K G)_{n=1-5}$, we noted that the length of the linker plays a crucial role in the ability of peptides to be efficiently conjugated to the OM scaffold [48].

\subsection{Mannan-Peptide Conjugate}

In the $\mathrm{OM}-(\mathrm{KG})_{5}-\mathrm{MOG}_{35-55}$ conjugate, unreacted aldehyde groups are necessary to immunoregulate the peptide to dendritic cells. This is a result of ethylene glycol addition to blockade further oxidation, and in line with previous studies on MUC1-mannan conjugates in cancer research, which required aldehyde groups in order to activate dendritic cells [39]. The matrix also contains intact mannose units, not oxidized, necessary to bind to the mannose receptor of the dendritic cells and their activation via toll-like receptor 4 [49-52]. In particular, the procedure we followed to produce the mannan-peptide conjugate allows: (i) the presence of antigen peptide $\mathrm{MOG}_{35-55}$ connected with aldehyde groups of the OM through immune bonds (Schiff base) with the amino groups of the lysine side chain in the (KG) $)_{5}-\mathrm{MOG}_{35-55}$ peptide. The peptide-OM conjugate is delivered to dendritic cells via the mannan scaffold for regulation of the immune system; (ii) the presence of unreacted aldehyde groups are necessary to modulate dendritic cells; and (iii) the presence intact mannose units, not oxidized, necessary to bind to the mannose receptor of the dendritic cells. 


\subsection{Chemistry of the Mannose Cleavage}

The cis-diols can form a cyclic complex upon oxidation with strong oxidizing agents as periodate. This allows the cleavage of the bond between the two carbons bearing the two hydroxyl groups, leading to the formation of aldehyde groups. Mannose is a carbohydrate, which holds two hydroxyl groups at positions 2,3 of the ring in a cis- position. This allows the oxidizing agent sodium periodate to form a cyclic complex, which finally leads to cleavage of the carbon-carbon bond bearing the cis-hydroxyl groups. This complex cannot be formed if the hydroxyl groups at the adjacent carbon atoms are in a trans position and subsequently this carbon-carbon bond cannot be cleaved. The formation of the cyclic mannose-periodate complex is leading finally to the cleavage of the ring and the formation of the two aldehyde groups. These groups react with the amino groups of the five lysines of the (KG) $)_{5}-\mathrm{MOG}_{35-55}$ to form double bond imines (Schiff base reaction) thus, the $\mathrm{MOG}_{35-55}$ peptide attached to the mannan scaffold. Figure 7 shows the mechanism of cis diol cleavage.

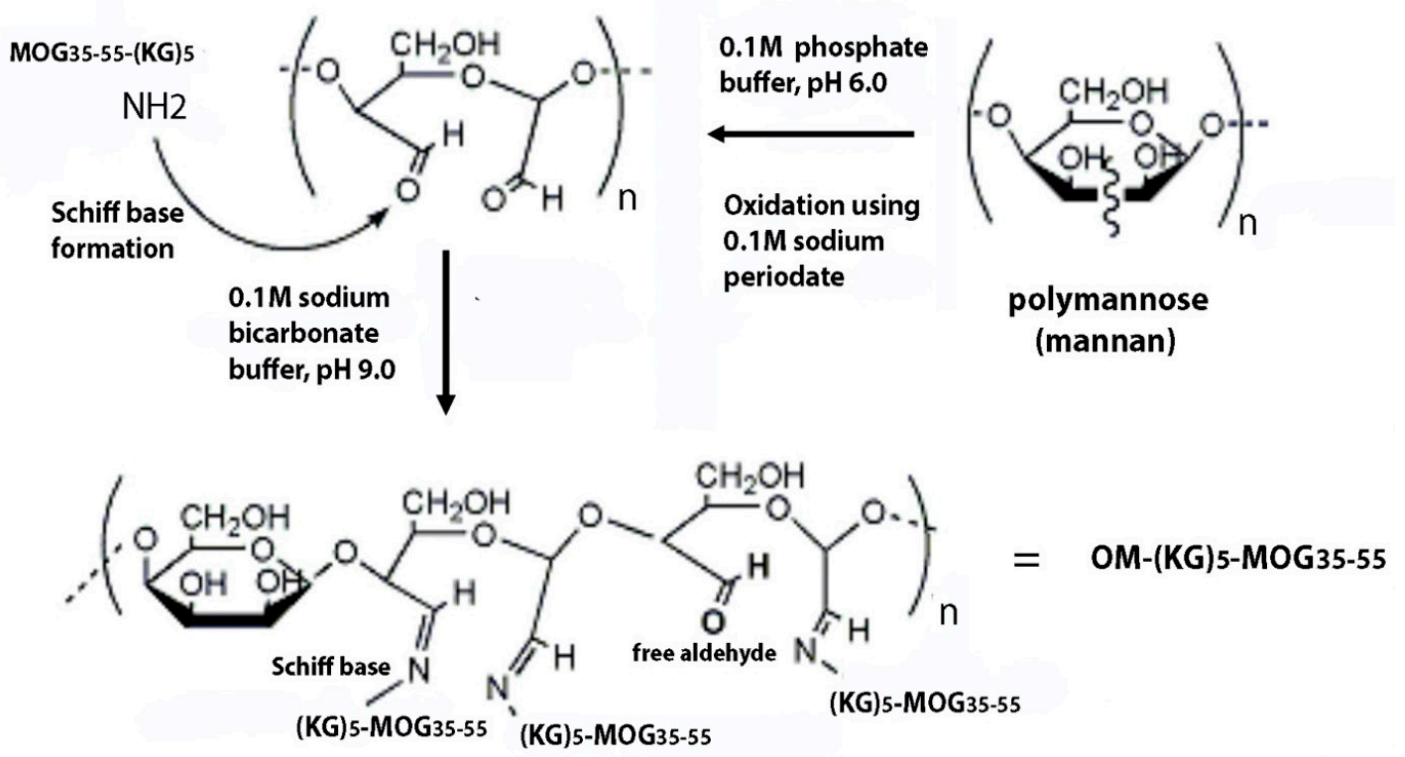

Figure 7. The mechanism of cis diol cleavage. Synthetic scheme of conjugation reaction of peptide with oxidized mannan [35].

\section{Conclusions}

We developed and confirm an analytical electrochemical method for monitoring the conjugation reaction of peptides to the carrier mannan; $(\mathrm{KG})_{5}-\mathrm{MOG}_{35-55}$ was used as the peptide example in this study. Peptide-OM conjugates can serve as potential vaccine candidates as has previously been shown by the group for cancer models and more recently in MS models. Electrochemical voltammetric techniques and HPLC experiments were used to confirm the conjugation of $(\mathrm{KG})_{5}-\mathrm{MOG}_{35-55}$ to the aldehyde groups of OM. It is shown that voltammetric technique and HPLC can be used to monitor the conjugation efficiency of peptide-carrier conjugates.

Supplementary Materials: The following are available online at http://www.mdpi.com/2076-3425/10/9/577/s1. Figure S1: EDS elemental microanalysis of a Graphite/ $/ \mathrm{SiO}_{2}$ film electrode.

Author Contributions: E.T. conceived and designed exclusively the electrochemical experiments. J.M. and V.A. conceived and designed the biochemical parts, the HPLC measurements and the chemistry of the mannose cleavage; E.D., S.P., E.T. and J.M. performed the experiments; E.T., J.M., E.D. and V.A. analyzed the data; E.T., J.M. and V.A. contributed to reagents/materials/analysis tools; E.D., E.T. and J.M. wrote their respective specialty parts of this paper; V.A. revised and edited the paper. All authors have read and agreed to the published version of the manuscript

Funding: This research was partially supported by Grant 80669 from the Research Committee of the University of Patras via C. CARATHEODORI program. 
Acknowledgments: The authors would like to thank Elias Sakellis from NCSR Demokritos for the SEM images and EDS analysis. V.A. would like to thank the Institute for Health and Sport, Victoria University, for supporting her current efforts into MS research. J.M. would like to thank the General Secretariat for Research and Technology (GSRT) for supporting his MS research.

Conflicts of Interest: The authors declare no conflict of interest.

\section{References}

1. Nosrati, R.; Olad, A.; Maryami, F. The use of graphite $/ \mathrm{TiO}_{2}$ nanocomposite additive for preparation of polyacrylic based visible-light induced antibacterial and self-cleaning coating. Res. Chem. Intermed. 2018, 44, 6219-6237. [CrossRef]

2. Nikolaou, P.; Deskoulidis, E.; Topoglidis, E.; Kakoulidou, A.T.; Tsopelas, F. Application of chemometrics for detection and modeling of adulteration of fresh cow milk with reconstituted skim milk powder using voltammetric fingerpriting on a graphite/ $\mathrm{SiO}_{2}$ hybrid electrode. Talanta 2020, 206, 120223. [CrossRef] [PubMed]

3. Nikolaou, P.; Vareli, I.; Deskoulidis, E.; Matsoukas, J.; Vassilakopoulou, A.; Koutselas, I.; Topoglidis, E. Graphite/ $\mathrm{SiO}_{2}$ film electrode modified with hybrid organic-inorganic perovskites: Synthesis, optical, electrochemical properties and application in electrochemical sensing of losartan. J. Solid State Chem. 2019, 273, 17-24. [CrossRef]

4. Topoglidis, E.; Kolozoff, P.-A.; Tiflidis, C.; Papavasiliou, J.; Sakellis, E. Adsorption and electrochemical behavior of Cyt-c on carbon nanotubes/ $/ \mathrm{TiO}_{2}$ nanocomposite films fabricated at various annealing temperatures. Colloid Polym. Sci. 2018, 296, 1353-1364. [CrossRef]

5. Dargahi, N.; Katsara, M.; Tselios, T.; Androutsou, M.E.; De Courten, M.; Matsoukas, J.; Apostolopoulos, V. Multiple sclerosis: Immunopathology and treatment update. Brain Sci. 2017, 7. [CrossRef]

6. Katsara, M.; Apostolopoulos, V. Editorial: Multiple Sclerosis: Pathogenesis and Therapeutics. Med. Chem. 2018, 14, 104-105. [CrossRef]

7. Katsara, M.; Matsoukas, J.; Deraos, G.; Apostolopoulos, V. Towards immunotherapeutic drugs and vaccines against multiple sclerosis. Acta Biochim. Biophys. Sin. 2008, 40, 636-642. [CrossRef]

8. Katsara, M.; Tselios, T.; Deraos, S.; Deraos, G.; Matsoukas, M.T.; Lazoura, E.; Matsoukas, J.; Apostolopoulos, V. Round and round we go: Cyclic peptides in disease. Curr. Med. Chem. 2006, 13, 2221-2232. [CrossRef]

9. Steinman, L. Multiple sclerosis: A coordinated immunological attack against myelin in the central nervous system. Cell 1996, 85, 299-302. [CrossRef]

10. Steinman, L. Multiple sclerosis: A two-stage disease. Nat. Immunol. 2001, 2, 762-764. [CrossRef]

11. Candia, M.; Kratzer, B.; Pickl, W.F. On Peptides and Altered Peptide Ligands: From Origin, Mode of Action and Design to Clinical Application (Immunotherapy). Int. Arch. Allergy Immunol. 2016, 170, 211-233. [CrossRef] [PubMed]

12. Katsara, M.; Minigo, G.; Plebanski, M.; Apostolopoulos, V. The good, the bad and the ugly: How altered peptide ligands modulate immunity. Expert Opin. Biol. Ther. 2008, 8, 1873-1884. [CrossRef] [PubMed]

13. Katsara, M.; Yuriev, E.; Ramsland, P.A.; Deraos, G.; Tselios, T.; Matsoukas, J.; Apostolopoulos, V. A double mutation of MBP(83-99) peptide induces IL-4 responses and antagonizes IFN-gamma responses. J. Neuroimmunol. 2008, 200,77-89. [CrossRef]

14. Katsara, M.; Yuriev, E.; Ramsland, P.A.; Deraos, G.; Tselios, T.; Matsoukas, J.; Apostolopoulos, V. Mannosylation of mutated MBP83-99 peptides diverts immune responses from Th1 to Th2. Mol. Immunol. 2008, 45, 3661-3670. [CrossRef]

15. Katsara, M.; Yuriev, E.; Ramsland, P.A.; Tselios, T.; Deraos, G.; Lourbopoulos, A.; Grigoriadis, N.; Matsoukas, J.; Apostolopoulos, V. Altered peptide ligands of myelin basic protein (MBP87-99) conjugated to reduced mannan modulate immune responses in mice. Immunology 2009, 128, 521-533. [CrossRef]

16. Trager, N.N.M.; Butler, J.T.; Harmon, J.; Mount, J.; Podbielska, M.; Haque, A.; Banik, N.L.; Beeson, C.C. A Novel Aza-MBP Altered Peptide Ligand for the Treatment of Experimental Autoimmune Encephalomyelitis. Mol. Neurobiol. 2018, 55, 267-275. [CrossRef]

17. Katsara, M.; Deraos, S.; Tselios, T.V.; Pietersz, G.; Matsoukas, J.; Apostolopoulos, V. Immune responses of linear and cyclic PLP139-151 mutant peptides in SJL/J mice: Peptides in their free state versus mannan conjugation. Immunotherapy 2014, 6, 709-724. [CrossRef] 
18. Lourbopoulos, A.; Deraos, G.; Matsoukas, M.T.; Touloumi, O.; Giannakopoulou, A.; Kalbacher, H.; Grigoriadis, N.; Apostolopoulos, V.; Matsoukas, J. Cyclic MOG35-55 ameliorates clinical and neuropathological features of experimental autoimmune encephalomyelitis. Bioorg. Med. Chem. 2017, 25, 4163-4174. [CrossRef]

19. Lourbopoulos, A.; Matsoukas, M.T.; Katsara, M.; Deraos, G.; Giannakopoulou, A.; Lagoudaki, R.; Grigoriadis, N.; Matsoukas, J.; Apostolopoulos, V. Cyclization of PLP139-151 peptide reduces its encephalitogenic potential in experimental autoimmune encephalomyelitis. Bioorg. Med. Chem. 2018, 26, 2221-2228. [CrossRef]

20. Apostolopoulos, V.; Rostami, A.; Matsoukas, J. The Long Road of Immunotherapeutics against Multiple Sclerosis. Brain Sci. 2020, 10. [CrossRef]

21. Day, S.; Tselios, T.; Androutsou, M.E.; Tapeinou, A.; Frilligou, I.; Stojanovska, L.; Matsoukas, J.; Apostolopoulos, V. Mannosylated Linear and Cyclic Single Amino Acid Mutant Peptides Using a Small 10 Amino Acid Linker Constitute Promising Candidates Against Multiple Sclerosis. Front. Immunol. 2015, 6, 136. [CrossRef] [PubMed]

22. Deraos, G.; Rodi, M.; Kalbacher, H.; Chatzantoni, K.; Karagiannis, F.; Synodinos, L.; Plotas, P.; Papalois, A.; Dimisianos, N.; Papathanasopoulos, P.; et al. Properties of myelin altered peptide ligand cyclo(87-99)(Ala91,Ala96)MBP87-99 render it a promising drug lead for immunotherapy of multiple sclerosis. Eur. J. Med. Chem. 2015, 101, 13-23. [CrossRef] [PubMed]

23. Tapeinou, A.; Androutsou, M.E.; Kyrtata, K.; Vlamis-Gardikas, A.; Apostolopoulos, V.; Matsoukas, J.; Tselios, T. Conjugation of a peptide to mannan and its confirmation by tricine sodium dodecyl sulfate-polyacrylamide gel electrophoresis. Anal. Biochem. 2015, 485, 43-45. [CrossRef] [PubMed]

24. Tselios, T.V.; Lamari, F.N.; Karathanasopoulou, I.; Katsara, M.; Apostolopoulos, V.; Pietersz, G.A.; Matsoukas, J.M.; Karamanos, N.K. Synthesis and study of the electrophoretic behavior of mannan conjugates with cyclic peptide analogue of myelin basic protein using lysine-glycine linker. Anal. Biochem. 2005, 347, 121-128. [CrossRef]

25. Apostolopoulos, V.; Pietersz, G.A.; Tsibanis, A.; Tsikkinis, A.; Drakaki, H.; Loveland, B.E.; Piddlesden, S.J.; Plebanski, M.; Pouniotis, D.S.; Alexis, M.N.; et al. Pilot phase III immunotherapy study in early-stage breast cancer patients using oxidized mannan-MUC1 [ISRCTN71711835]. Breast Cancer Res. 2006, 8, R27. [CrossRef]

26. Apostolopoulos, V.; Pietersz, G.A.; Tsibanis, A.; Tsikkinis, A.; Stojanovska, L.; McKenzie, I.F.; Vassilaros, S. Dendritic cell immunotherapy: Clinical outcomes. Clin. Transl. Immunol. 2014, 3, e21. [CrossRef]

27. Karanikas, V.; Hwang, L.A.; Pearson, J.; Ong, C.S.; Apostolopoulos, V.; Vaughan, H.; Xing, P.X.; Jamieson, G.; Pietersz, G.; Tait, B.; et al. Antibody and T cell responses of patients with adenocarcinoma immunized with mannan-MUC1 fusion protein. J. Clin. Investig. 1997, 100, 2783-2792. [CrossRef]

28. Karanikas, V.; Lodding, J.; Maino, V.C.; McKenzie, I.F. Flow cytometric measurement of intracellular cytokines detects immune responses in MUC1 immunotherapy. Clin. Cancer Res. 2000, 6, 829-837.

29. Karanikas, V.; Thynne, G.; Mitchell, P.; Ong, C.S.; Gunawardana, D.; Blum, R.; Pearson, J.; Lodding, J.; Pietersz, G.; Broadbent, R.; et al. Mannan Mucin-1 Peptide Immunization: Influence of Cyclophosphamide and the Route of Injection. J. Immunother 2001, 24, 172-183. [CrossRef]

30. Loveland, B.E.; Zhao, A.; White, S.; Gan, H.; Hamilton, K.; Xing, P.X.; Pietersz, G.A.; Apostolopoulos, V.; Vaughan, H.; Karanikas, V.; et al. Mannan-MUC1-pulsed dendritic cell immunotherapy: A phase I trial in patients with adenocarcinoma. Clin. Cancer Res. 2006, 12, 869-877. [CrossRef]

31. Mitchell, P.L.; Quinn, M.A.; Grant, P.T.; Allen, D.G.; Jobling, T.W.; White, S.C.; Zhao, A.; Karanikas, V.; Vaughan, H.; Pietersz, G.; et al. A phase 2, single-arm study of an autologous dendritic cell treatment against mucin 1 in patients with advanced epithelial ovarian cancer. J. Immunother Cancer 2014, 2, 16. [CrossRef]

32. Vassilaros, S.; Tsibanis, A.; Tsikkinis, A.; Pietersz, G.A.; McKenzie, I.F.; Apostolopoulos, V. Up to 15-year clinical follow-up of a pilot Phase III immunotherapy study in stage II breast cancer patients using oxidized mannan-MUC1. Immunotherapy 2013, 5, 1177-1182. [CrossRef] [PubMed]

33. Deraos, G.; Chatzantoni, K.; Matsoukas, M.T.; Tselios, T.; Deraos, S.; Katsara, M.; Papathanasopoulos, P.; Vynios, D.; Apostolopoulos, V.; Mouzaki, A.; et al. Citrullination of linear and cyclic altered peptide ligands from myelin basic protein (MBP(87-99)) epitope elicits a Th1 polarized response by T cells isolated from multiple sclerosis patients: Implications in triggering disease. J. Med. Chem. 2008, 51, 7834-7842. [CrossRef] [PubMed] 
34. Matsoukas, J.; Apostolopoulos, V.; Kalbacher, H.; Papini, A.M.; Tselios, T.; Chatzantoni, K.; Biagioli, T.; Lolli, F.; Deraos, S.; Papathanassopoulos, P.; et al. Design and synthesis of a novel potent myelin basic protein epitope 87-99 cyclic analogue: Enhanced stability and biological properties of mimics render them a potentially new class of immunomodulators. J. Med. Chem. 2005, 48, 1470-1480. [CrossRef] [PubMed]

35. Tselios, T.; Apostolopoulos, V.; Daliani, I.; Deraos, S.; Grdadolnik, S.; Mavromoustakos, T.; Melachrinou, M.; Thymianou, S.; Probert, L.; Mouzaki, A.; et al. Antagonistic effects of human cyclic MBP(87-99) altered peptide ligands in experimental allergic encephalomyelitis and human T-cell proliferation. J. Med. Chem. 2002, 45, 275-283. [CrossRef]

36. Song, M.-J.; Hwang, S.W.; Whang, D. Amperometric hydrogen peroxide biosensor based on a modified gold electrode with silver nanowires. J. Appl. Electrochem. 2010, 40, 2099-2105. [CrossRef]

37. Konopka, S.J.; McDuffie, B. Diffusion coefficients of ferri-and ferrocyanide ions in aqueous media, using twin-electrode thin-layer electrochemistry. Anal. Chem. 1970, 42, 1741-1746. [CrossRef]

38. Hussain, G.; Silvester, D.S. Comparison of Voltammetric Techniques for Ammonia Sensing in Ionic Liquids. Electroanalysis 2018, 30, 75-83. [CrossRef]

39. Apostolopoulos, V.; Pietersz, G.A.; Gordon, S.; Martinez-Pomares, L.; McKenzie, I.F. Aldehyde-mannan antigen complexes target the MHC class I antigen-presentation pathway. Eur. J. Immunol. 2000, 30, 1714-1723. [CrossRef]

40. Apostolopoulos, V.; Pietersz, G.A.; Loveland, B.E.; Sandrin, M.S.; McKenzie, I.F. Oxidative/reductive conjugation of mannan to antigen selects for T1 or T2 immune responses. Proc. Natl. Acad. Sci. USA 1995, 92, 10128-10132. [CrossRef]

41. Grunwald, J.; Rejtar, T.; Sawant, R.; Wang, Z.; Torchilin, V.P. TAT peptide and its conjugates: Proteolytic stability. Bioconjug. Chem. 2009, 20, 1531-1537. [CrossRef]

42. Lemus, R.; Karol, M.H. Conjugation of haptens. Methods Mol. Med. 2008, 138, 167-182. [CrossRef]

43. Berthet, M.; Martinez, J.; Parrot, I. $\mathrm{MgI}_{2}$-chemoselective cleavage for removal of amino acid protecting groups: A fresh vision for peptide synthesis. Biopolymers 2017, 108. [CrossRef]

44. Isidro-Llobet, A.; Alvarez, M.; Albericio, F. Amino acid-protecting groups. Chem. Rev. 2009, 109, $2455-2504$. [CrossRef]

45. Apostolopoulos, V.; Deraos, G.; Matsoukas, M.T.; Day, S.; Stojanovska, L.; Tselios, T.; Androutsou, M.E.; Matsoukas, J. Cyclic citrullinated MBP87-99 peptide stimulates T cell responses: Implications in triggering disease. Bioorg. Med. Chem. 2017, 25, 528-538. [CrossRef] [PubMed]

46. Pagba, C.V.; McCaslin, T.G.; Veglia, G.; Porcelli, F.; Yohannan, J.; Guo, Z.; McDaniel, M.; Barry, B.A. A tyrosine-tryptophan dyad and radical-based charge transfer in a ribonucleotide reductase-inspired maquette. Nat. Commun. 2015, 6, 10010. [CrossRef] [PubMed]

47. Zhai, J.; Zhao, L.; Zheng, L.; Gao, F.; Gao, L.; Liu, R.; Wang, Y.; Gao, X. Peptide-Au Cluster Probe: Precisely Detecting Epidermal Growth Factor Receptor of Three Tumor Cell Lines at a Single-Cell Level. ACS Omega 2017, 2, 276-282. [CrossRef] [PubMed]

48. Tapeinou, A. Design, synthesis and evaluation of analogues of myelin protein immunodominant epitopes implemented in multiple sclerosis. Eur. J. Med. Chem. 2017, 143, 621-631. [CrossRef] [PubMed]

49. Apostolopoulos, V.; Barnes, N.; Pietersz, G.A.; McKenzie, I.F. Ex vivo targeting of the macrophage mannose receptor generates anti-tumor CTL responses. Vaccine 2000, 18, 3174-3184. [CrossRef]

50. Apostolopoulos, V.; Pietersz, G.A.; McKenzie, I.F. Cell-mediated immune responses to MUC1 fusion protein coupled to mannan. Vaccine 1996, 14, 930-938. [CrossRef]

51. Sheng, K.C.; Kalkanidis, M.; Pouniotis, D.S.; Wright, M.D.; Pietersz, G.A.; Apostolopoulos, V. The adjuvanticity of a mannosylated antigen reveals TLR4 functionality essential for subset specialization and functional maturation of mouse dendritic cells. J. Immunol. 2008, 181, 2455-2464. [CrossRef] [PubMed]

52. Sheng, K.C.; Pouniotis, D.S.; Wright, M.D.; Tang, C.K.; Lazoura, E.; Pietersz, G.A.; Apostolopoulos, V. Mannan derivatives induce phenotypic and functional maturation of mouse dendritic cells. Immunology 2006, 118, 372-383. [CrossRef] [PubMed]

(C) 2020 by the authors. Licensee MDPI, Basel, Switzerland. This article is an open access article distributed under the terms and conditions of the Creative Commons Attribution (CC BY) license (http://creativecommons.org/licenses/by/4.0/). 